\title{
Differences in age and topographic distribution of the different histological subtypes of basal cell carcinoma, Taubaté (SP), Brazil
}

\author{
Diferenças na idade e distribuição topográfica dos diferentes subtipos \\ histológicos de carcinoma basocelular, Taubaté (SP), Brasil
}

\author{
Flávia Regina Ferreira ${ }^{1}$ \\ Luiz Fernando Costa Nascimento ${ }^{3}$
}

\author{
Bruna da Costa Pevide ${ }^{2}$ \\ Marcia Lanzoni de Alvarenga Lira ${ }^{4}$
}

\author{
Rafaela Fabri Rodrigues ${ }^{2}$
}

\begin{abstract}
BACKGROUND: Basal cell carcinoma is the most common form of cancer in humans. OBJECTIVEs: To identify the epidemiology of basal cell carcinoma in Taubaté-SP and verify a possible association between topography and the different histological subtypes of this tumor. METHODS: This was a cross-sectional study conducted at The University Hospital of Taubaté between 01/01/08 and 12/31/09. The study included patients with a confirmed diagnosis of basal cell carcinoma, of both genders, without age restrictions. The variables studied were incidence of basal cell carcinoma, topography, histological subtype, skin color, age and gender. We employed the chi-square test to identify the association between histological subtype and topography, and the student's $t$ test to compare the mean age of onset for the different histological subtypes. RESULTS: The study included 239 individuals. The mean age of the sample was 68.0 years. Male subjects $(57.7 \%)$ and whites $(87.1 \%)$ predominated in the study. The predominant histological subtype was nodular (34.7\%), followed by the superficial subtype. The most frequent sites of involvement were the head and neck (areas exposed to light), with predominance of the nasal region. The superficial subtype was an exception, as it showed a strong association with unexposed areas like the trunk. The mean age of onset of superficial basal cell carcinoma also differed from that of the other histological subtypes, 63.0 and 69.0 years, respectively. ConCLusion: The results of this study suggest an association of the superficial histological subtype with younger patients and unexposed areas of the body, linking this type of tumor with a pattern of intermittent sun exposure, more similar to the standard photocarcinogenesis of melanoma.
\end{abstract}

Keywords: Carcinoma, basal cell; Histology; Topography

Resumo: FundAMENTOS: O carcinoma basocelular é a forma mais comum de câncer em humanos. OBjETIVos: Identificar a epidemiologia do carcinoma basocelular em Taubaté-SP e verificar possível associação entre a topografia e os diferentes subtipos histológicos deste tumor. MÉToDos: Estudo transversal e descritivo realizado no Hospital Universitário de Taubaté entre 01/01/08 e 31/12/09. Foram incluídos neste estudo indivíduos com diagnóstico confirmado de carcinoma basocelular, de ambos os gêneros, sem restrição quanto a idade. As variáveis estudadas foram ocorrência do carcinoma basocelular, topografia, subtipo histológico, cor da pele, idade e gênero. Foi utilizado o teste do qui-quadrado para identificar associação entre o subtipo histológico e a topografia, e o teste $\mathrm{t}$ de student para comparar a média de idade de acometimento entre os diferentes subtipos histológicos. RESULTADOS: Foram incluídos 239 indivíduos.A média de idade da amostra foi de 68,0 anos. O gênero masculino foi o mais prevalente $(57,7 \%)$, assim como a pele branca( $87,1 \%)$.O subtipo histológico predominante foi o nodular( $34,7 \%)$, seguido do subtipo superficial.A localização mais frequente foi a região de cabeça e pescoço(área fotoexposta), com predomínio da região nasal. Exceção para o subtipo superficial que mostrou forte associação com áreas cobertas como o tronco. A média de idade de incidência do carcinoma basocelular superficial também diferiu dos demais subtipos histológicos, 63.0 e 69.0 anos, respectivamente. ConcLusÃo: Os resultados sugerem associação do subtipo histológico superficial com faixas etárias mais jovens e áreas cobertas, relacionando o mesmo com um padrão de exposição solar intermitente, mais semelhante ao padrão de fotocarcinogênese do melanoma.

Palavras-chave: Carcinoma basocelular; Histologia; Topografia

Received on 20.09.2012.

Approved by the Advisory Board and accepted for publication on 18.11.2012.

* Work conducted at the University Hospital of Taubaté - University of Taubaté (HUT-UNITAU) - Taubaté (SP), Brazil.

Financial support: None.

Conflict of interests: None

M.Sc., Federal University of São Paulo (UNIFESP) - Assistant Professor III- School of Medicine, University of Taubaté (UNITAU) - Taubaté (SP), Brazil.

Student of Medicine, University of Taubaté (UNITAU) - Taubaté (SP), Brazil

PhD - Assistant Professor - School of Medicine, University of Taubaté (UNITAU) - Taubaté (SP), Brazil.

Pathologist - Assistant Professor of Pathology, School of Medicine, University of Taubaté (UNITAU) - Taubaté (SP), Brazil. 


\section{INTRODUCTION}

Cancer is a public health issue worldwide. In developed countries, cancer is the second cause of death after cardiovascular diseases. Basal cell carcinoma (BCC) is the most common malignancy in humans, accounting for $50 \%$ of cases. ${ }^{1}$

This tumor affects mainly fair-skinned individuals over 40 years old. Its preferred areas of involvement are the upper two thirds of the face, which are usually chronically exposed to the sun. ${ }^{2,3,4}$ Exposure to ultraviolet light, especially of the type B spectrum (UV-B), is the major environmental factor in the pathogenesis of this carcinoma because it induces mutation of tumor suppressor genes. ${ }^{5}$

$\mathrm{BCC}$ is slow growing with local malignancy and a destructive characteristic, but it rarely results in metastasis. ${ }^{6}$ The most frequent clinical subtype is nodular-ulcerative, prevailing in sunexposed areas of the head and neck, followed by the superficial subtype, which is most common in the trunk region..$^{7.8}$

Diagnosis is clinical and confirmed by biopsy and histopathology. It is also useful for evaluation of the histological subtype, growth pattern and level of tumor invasion. ${ }^{8}$

Studies have shown that superficial BCCs markedly differ from other histological subtypes as to the mean age of onset, affecting younger patients, and their topographic distribution, predominating in the trunk. These data are in agreement with the distribution patterns of melanomas, suggesting a possible relationship with intermittent sun exposure.,12

The objective of this study was to analyze the epidemiological pattern of basal cell carcinoma at the Dermatology Outpatient Clinic of the University Hospital of Taubaté and verify a possible association between topography and the different histological subtypes of this tumor.

\section{METHODS}

This was a cross-sectional study conducted at the University Hospital of Taubaté. The data were obtained from medical reports of histopathological examinations of patients seen at the Dermatology Outpatient Clinic of the University Hospital of Taubaté from January 12008 to December 312009 with a confirmed diagnosis of basal cell carcinoma. The material for histopathological examination was obtained through biopsy (incisional or excisional) or total surgical excision of the suspicious skin lesion done by professionals of the Dermatology Service.

The study included individuals of both genders with no age restrictions. Anonymity of the participants was maintained.

The variables studied were the incidence of BCC, topography divided into head and neck, trunk, upper limbs, lower limbs and unspecified, later grouped into exposed and non-exposed (covered) areas, histological subtype (nodular / nodular-ulcerative, superficial, sclerosing / sclerodermiform, micronodular and miscellaneous), skin color (white, nonwhite and unspecified), age, analyzed in a continuous manner and further categorized into 3 groups, and gender.

The development of a new tumor in a patient already included in the study was considered as a new case.

We used the chi-square test to identify the association between histological subtype and topography, and the Student's $t$ test to compare the mean ages of onset for the different histological subtypes of BCC.

The Ethics Research Committee of the University of Taubaté (UNITAU) approved this study under protocol No. 183/11.

\section{RESULTS}

The study included 239 patients with a confirmed histological diagnosis of basal cell carcinoma (BCC) seen at the University Hospital of Taubaté from January 12008 to December 31 2009; 138 (57.7\%) subjects were male and 101 (42.3\%) were female.

The mean age of the sample was 68 years $(\mathrm{SD}=$ 12.2); the minimum age was 34 years and the maximum age was 88 years. Most cases $(173-72.3 \%)$ involved patients older than 60 years. Only $3(1.2 \%)$ cases were detected in subjects under 40 years old and $57(23.8 \%)$ cases were seen in individuals aged between 40 and 60 years. Of the cases studied, age was unspecified in $4(1.6 \%)$ of them.

Considering the total number of individuals included in the study, $170(71.1 \%)$ provided information about their skin color; of these, 148 (87.1\%) were white and 22 (12.9\%) non-white.

With regard to histological subtypes, the nodular/nodular-ulcerative pattern predominated, accounting for $83(34.7 \%)$ cases, followed by the superficial subtype with $40(16.7 \%)$ cases. In 40 subjects $(16.7 \%)$ the histological pattern of the BCC was not specified. A complete analysis of the histological subtypes of BCC is found in table 1 .

In 179 (74.9\%) patients the tumor was located in the head and neck. The second most common site was the trunk (10.5\%), followed by upper $(9.6 \%)$ and lower limbs $(4.2 \%)$. In 2 cases $(0.8 \%)$ topography was not specified.

With regard to the location of the BCC in the cephalic segment, there was predominance of the tumor in the nasal region, with $51(28.4 \%)$ cases, followed by the frontotemporal region with 44 (24.5\%) cases. There was low predominance of this tumor in 
the mandibular, labial and mentonian regions.

The association between gender and location of the tumor revealed that tumors predominated in the head and neck of both male and female patients (Table 2).

We observed prevalence of the superficial subtype in unexposed areas (trunk) and of the other subtypes in sun-exposed areas, mainly in the head and neck.

Table 3 shows a detailed analysis of the histological subtypes of BCC in relation to topography.

TABle 1: Distribution of the histological subtypes of BCC, absolute values and percentages. Taubaté, Brazil - 2008-2009

\begin{tabular}{lll}
\hline Histological Subtypes & $\mathbf{N}$ & $\%$ \\
\hline Nodular / Nodular-ulcerative & 83 & 34.7 \\
Superficial & 40 & 16.7 \\
Sclerosing / sclerodermiform & 26 & 10.9 \\
Micronodular & 5 & 2.1 \\
Miscellaneous* & 45 & 18.8 \\
Unspecified & 40 & 16.7 \\
\hline Total & $\mathbf{2 3 9}$ & $\mathbf{1 0 0 . 0}$ \\
\hline
\end{tabular}

* Pigmented, mixed and ulcerated BCC

TABLE 2: Distribution of BCC cases by gender and topography, absolute values and percentages. Taubaté, Brazil - 2008-2009 *

\begin{tabular}{lllllllllll}
\hline Gender & \multicolumn{2}{l}{ Head / Neck } & \multicolumn{2}{c}{ Trunk } & \multicolumn{2}{c}{ Arms } & \multicolumn{2}{c}{ Legs } & \multicolumn{2}{c}{ Total } \\
& $\mathbf{N}$ & $\mathbf{0}$ & $\mathbf{N}$ & $\mathbf{0}$ & $\mathbf{N}$ & $\mathbf{0}$ & $\mathbf{N}$ & $\mathbf{\%}$ & $\mathbf{N}$ & $\%$ \\
\hline Male & 101 & $(56.4)$ & 16 & $(64.0)$ & 17 & $(74.0)$ & 3 & $(30.0)$ & 137 & $(57.8)$ \\
Female & 78 & $(43.6)$ & 9 & $(36.0)$ & 6 & $(26.0)$ & 7 & $(70.0)$ & 100 & $(42.2)$ \\
\hline Total & $\mathbf{1 7 9}$ & $\mathbf{( 1 0 0 . 0 )}$ & $\mathbf{2 5}$ & $\mathbf{( 1 0 0 . 0 )}$ & $\mathbf{2 3}$ & $\mathbf{( 1 0 0 . 0 )}$ & $\mathbf{1 0}$ & $\mathbf{( 1 0 0 . 0 )}$ & $\mathbf{2 3 7}$ & $\mathbf{( 1 0 0 . 0 )}$ \\
\hline
\end{tabular}

* Considering only cases for which topography was specified.

TABLE 3: Distribution of cases by histological subtype and topography, absolute values and percentages. Taubaté, Brazil - 2008-2009*

\begin{tabular}{llllllllllllll}
\hline Topography & \multicolumn{1}{c}{ Histological Subtypes ** } \\
\hline & $\mathbf{1}$ & & $\mathbf{2}$ & & $\mathbf{3}$ & & $\mathbf{4}$ & & $\mathbf{5}$ & \multicolumn{3}{c}{ Total } \\
& $\mathbf{N}$ & $\%$ & $\mathbf{N}$ & $\%$ & $\mathbf{N}$ & $\%$ & $\mathbf{N}$ & $\%$ & $\mathbf{N}$ & $\%$ & $\mathbf{N}$ & $\%$ \\
\hline Head / neck & 68 & $(81.9)$ & 10 & $(25.0)$ & 24 & $(92.3)$ & 5 & $(100.0)$ & 36 & $(83.7)$ & 143 & $(72.5)$ \\
Trunk & 4 & $(4.8)$ & 15 & $(37.5)$ & 0 & $(0.0)$ & 0 & $(0.0)$ & 4 & $(9.3)$ & 23 & $(11.6)$ \\
Arms & 9 & $(10.8)$ & 9 & $(22.5)$ & 2 & $(7,6)$ & 0 & $(0.0)$ & 1.2 .3 & 21 & $(10.6)$ \\
Lower limbs & 2 & $(2,4)$ & 6 & $(15.0)$ & 0 & $(0.0)$ & 0 & $(0.0)$ & 2 & $(4,6)$ & 10 & $(5.0)$ \\
\hline Total & $\mathbf{8 3}$ & $\mathbf{( 1 0 0 . 0 )}$ & $\mathbf{4 0}$ & $\mathbf{( 1 0 0 . 0 )}$ & $\mathbf{2 6}$ & $\mathbf{( 1 0 0 . 0 )}$ & $\mathbf{5}$ & $\mathbf{( 1 0 0 . 0 )}$ & $\mathbf{4 3}$ & $\mathbf{( 1 0 0 . 0 )}$ & $\mathbf{1 9 7}$ & $\mathbf{( 1 0 0 . 0 )}$ \\
\hline
\end{tabular}

* Considering only cases for which histological subtype and topography were specified.

Histological Subtypes ** 1 = Nodular / Nodular-ulcerative, $2=$ Superficial, $3=$ Sclerosing $/$ sclerodermiform; micronodular = 4, $5=$ Miscellaneous. 
This research included 239 patients with histologically confirmed BCC seen at the University Hospital of Taubaté from January 12008 to December 312009.

Findings in relation to gender were controversial ( $57.7 \%$ men and $42.3 \%$ women). These findings are similar to those of earlier studies in which male subjects predominated and differ from those of recent work in which females prevail. ${ }^{13-17}$ This inversion of prevalence may be associated with new concepts of beauty, such as the "culture of tanned skin", with an increasing demand for natural and artificial tanning, the female revolution (twentieth century) with a higher participation of women in the labor market and in activities previously done exclusively by men, and the fact that the female population is the target audience for several educational campaigns against cancer, making women more aware and careful about their own body. ${ }^{13,15}$

The mean age of the sample was 68.0 years, with the disease predominating in patients older than 60 years $(72.3 \%)$. These results are similar to those found in the literature, but they differ from those of a study by Nasser, in which there was greater incidence of the disease in the age group between 40 and 60 years. ${ }^{9,18,19}$ Perhaps this finding is due to the fairskinned population profile of this region of the country (South region), which favors an earlier development of BCC.

In relation to ethnicity, $87.1 \%$ were white and $12.9 \%$ were non-white. Predominance of BCC in fairskinned individuals is nearly a consensus in the literature. ${ }^{9,15,16,18-22}$ Caucasians have the highest rates of skin cancer, especially those who tend to burn rather than tan when exposed to sunlight (skin phototypes I and II according to Fitzpatrick classification). ${ }^{20}$

There was a marked predominance of BCC in the head and neck $(74.9 \%)$ in both genders, with these regions being the main areas of sun-exposed skin. This reinforces chronic sun exposure as a risk factor for BCC, corroborating findings in the literature. , $10,15,20-22^{2}$

In the head, the nasal region was the most affected, which is also consistent with results in the literature. ${ }^{10,171,1920}$ Considering the division of the face in upper third (between the hairline and the eyebrows), middle third (between the eyebrows and the subnasal area) and lower third (between the subnasal area and the mentonian region), there is significant prevalence of BCC in the upper two-thirds of the face, which is also in agreement with data from the literature. ${ }^{14,17,20,22}$

By correlating gender with the location of the tumor, it was observed that the predominant locations were the head and neck in both genders; however, there were gender differences in other locations. BCC in the trunk predominated in males $(64.0 \%)$, which is probably due to greater exposure of this body part during work or leisure activities. ${ }^{15}$ BCC in the lower limbs predominated in females $(70.0 \%)$, perhaps due to the fact that women sometimes wear clothes that expose this region of their body.

The occurrence of BCC in unexposed areas and the rare involvement of typically exposed areas such as the dorsum of hands indicate that other factors may be involved in the genesis of this disease. ${ }^{21}$

The most prevalent histological subtype in this study was nodular/nodular-ulcerative (34.7\%), agreeing with the findings of Mantese et al., and Bandeira et al., but differing from the findings of Nasser, which classify the superficial subtype as the most prevalent. ${ }^{10,19,23}$

By analyzing the relation between histological subtype/tumor (BCC) topography, we found a predominance of the nodular/nodular-ulcerative, sclerodermiform, micronodular and miscellaneous (pigmented, mixed and ulcerated) subtypes in the head and neck (area of continuous sun exposure). The superficial subtype predominated in the trunk region (area of intermittent sun exposure). These findings were consistent with those of the literature., ${ }^{9} 12$

Comparing the mean age of onset of superficial BCC and that of the other histological subtypes of BCC, the superficial subtype differed markedly, affecting younger individuals (63.0 years), while the other subtypes affected older individuals (69.0 years). This finding is in agreement with studies by Vries et al and McCormack., ${ }^{9,24}$

In this study superficial BCC differed from the other histological subtypes of BCC with regard to the mean age of onset and its topographic distribution. These data on topography are in agreement with the distribution patterns of superficial spreading (unexposed area) and nodular (sun-exposed area) melanomas, suggesting a possible relationship of superficial BCC with intermittent sun exposure and of the other subtypes with cumulative sun exposure. ${ }^{9-12}$

\section{CONCLUSION}

This study revealed the epidemiological profile of patients with basal cell carcinoma (BCC) treated at the University Hospital of Taubaté in Taubaté-SP, from January 12008 to December 31 2009. It showed that superficial BCC affects younger patients and areas of the body unexposed to sunlight, associating this subtype with a pattern of intermittent sun exposure, more similar to the standard photocarcinogenesis of melanoma. The other histological subtypes of BCC show greater predilection for sun-exposed areas and older individuals and are associated with continuous sun exposure. 


\section{REFERENCES}

1. Lopes A, lyeyasu H, Lopes LF, Castro RMRPS, Organizadores. Oncologia para a graduação. Ribeirão Preto: Tecmedd; 2005.

2. Azulay RD, Azulay DR. Dermatologia. 3. ed. Rio de Janeiro: Guanabara Koogan; 2004.

3. Ferreira FR, Nascimento LFC, Rotta 0. Fatores de risco para câncer da pele não melanoma em Taubaté, SP: um estudo caso-controle. Rev Assoc Med Bras. 2011; 57:431-7.

4. Sampaio SAP, Rivitti EA. Dermatologia. 2. ed. São Paulo: Artes Médicas; 2001.

5. União Internacional Contra o Câncer (UICC). Manual de Oncologia Clínica da UICC. 8 ed. São Paulo: Fundação Oncocentro de São Paulo; 2006.

6. Kumar V, Abbas AK, Fausto N. Robbins e Cotran: Patologia: Bases patológicas das Doenças. 7 ed. Rio de Janeiro: Elsevier; 2005.

7. Belda Junior W, Di Chiacchio N, Criado PR. Tratado de dermatologia. vol. 2. São Paulo: Editora Atheneu; 2010.

8. Rotta 0. Guia de Dermatologia: clinica, cirúrgica e cosmiátrica. Barueri: Manole; 2008.

9. McCormack CJ, Kelly JW, Dorevitch AP. Differences in age and body site distribution of the histological subtypes of basal cell carcinoma. Arch Dermatol. 1997:133:593-6.

10. Mantese SAO, Berbert ALCV, Gomides MDA, Rocha A. Basal cell Carcinoma - Analysis of 300 cases observed in Uberlândia - MG, Brazil. An Bras Dermatol. 2006;81:136-42.

11. Scrivener $Y$, Grosshans $E$, Cribier B. Variations of basal cell carcinomas according to gender, age, location and histopathological subtype. Br J Dermatol. 2002;147:41-7.

12. Bastiaens MT, Hoefnagel JJ, Bruijn JA, Westendorp RG, Vermeer BJ, Bouwes Bavinck JN. Differences in age, site distribution, and sex between nodular and superficial basal cell carcinomas indicate different types of tumors. J Invest Dermatol. 1998;110: 880-4.

13. Castro LGM, Freire MA, Toyama CL, Brito TL, Gomes AP. Câncer de pele em clínica particular em São Paulo - SP. An Bras Dermatol. 1996;71:471-6.

14. Costa LAL, Fernandes GO, Kanazawa LS, Miranda JG, Pretti H. Análise facial - Uma revisão de literatura. J Bras Ortodon Ortop Facial. 2004;9:171-6.

15. Ferreira FR, Nascimento LFC. Skin cancer in Taubaté (SP) - Brazil, from 2001 to 2005: a prevalence study. An Bras Dermatol. 2008;83:317-22.

16. Lear W, Dahlke E, Murray CA. Basal cell carcinoma: review of epidemiology, pathogenesis, and associated risk factors. J Cutan Med Surg. 2007;11:19-30.

17. Custódio G, Locks LH, Coan MF, Gonçalves CO, Trevisol DJ, Trevisol FS. Epidemiology of basal cell carcinomas in Tubarão, Santa Catarina (SC), Brazil between 1999 and 2008. An Bras Dermatol. 2010;85:819-26.

18. Green A, Whiteman D, Frost C, Battistutta D. Sun exposure, Skin cancers and related skin conditions. J Epidemiol. 1999:9:S7-13.

19. Nasser N. Epidemiology of basal cell carcinomas in Blumenau, SC, Brazil, from 1980 to 1999. An Bras Dermatol. 2005;80:363-8.

20. Gon AS. Fatores de risco para o carcinoma basocelular: estudo de casos e controles [tese]. Londrina (PR): Universidade Estadual de Londrina; 2008.

21. Chinem VP, Miot HA. Epidemiology of basal cell carcinoma. An Bras Dermatol. 2011;86:292305.

22. Souza FDS, Thomé EP, Menegotto PF, Schmitt JV, Shibue JRT, Tarlé RG. Topography of basal cell carcinoma and their correlations with gender, age and histologic pattern: a retrospective study of 1042 lesions. An Bras Dermatol. 2011; 86:272-7.

23. Bandeira AM, Da Siva VB, Da Silva JF, Mazza E. Basal cell carcinomas: anatomopathological and clinical study of 704 tumors. An Bras Dermatol. 2003;78:23-34.

24. de Vries E, Louwman M, Bastiaens M, de Gruijl F, Coebergh JW. Rapid and continuous increases in incidence rates of basal cell carcinoma in the southeast Netherlands since 1973. J Invest Dermatol. 2004;123:634-8.

\author{
MAILING ADDRESS: \\ Flávia Regina Ferreira \\ Avenida Granadeiro Guimarães, 270 \\ 12100-000 - Taubaté - SP \\ Brazil \\ E-mail:dermagica@uol.com.br
}

How to cite this article: Ferreira FR, Pevide BC, Rodrigues RF, Nascimento LFC, Alvarenga Lira ML. Differences in age and topographic distribution of the different histological subtypes of basal cell carcinoma, Taubaté (SP), Brazil. An Bras Dermatol. 2013;88(5):726-30. 